\title{
Greenhouse Gases Assessment in the Context of the Covid-19 Pandemic
}

\author{
Monica Emanuela Stoica ${ }^{1 *}$ \\ ${ }^{1}$ PGU, DPTH Department, 100560, Ploiesti, Romania
}

\begin{abstract}
Greenhouse gases are: carbon dioxide, methane, nitrous oxide, hydrofluorocarbons, perfluorocarbons and sulfur hexafluoride. In December 2020, the European Council approved a new target for reducing greenhouse gas emissions by 2030 and a net domestic emission reduction of at least $55 \%$ compared to 1990 , and climate neutrality for 2050 . Careful monitoring of emissions is needed to achieve these goals. The paper aims to evaluate and compare the carbon dioxide emission coefficient, in the case of burning different fuels: petroleum fuels and biofuels. The calculation model was developed based on the mathematical relationships taken from specific publications. Kerosene, Liquiefied Petroleum Gas, Gasoline COR 95 Euro 5 and Diesel Euro 5 are the petroleum fuels used in the study. The used biofuels are: Bioethanol, Biobuthanol, Biodiesel (soybean) and Biodiesel (rapeseed). The results provide data on the amount of $\mathrm{CO}_{2}$ that reaches into the atmosphere. Based on the information obtained, a fuel ranking can be made and decisions can be taken regarding their choice.
\end{abstract}

\section{Introduction}

Carbon dioxide, methane and nitrogen protoxide are the main greenhouse gases. They prevent the release of terrestrial heat into space, causing global warming.

The concept of sustainable development is part of the strategy of the European environment policy. It also refers to the reduction of the greenhouse gas (GHG) emissions $[1,2]$. The European Union (EU), through its policies, is involved in combating greenhouse gas emissions (GHG). By 2018, it has reduced the greenhouse gas emissions by $23 \%$ from 1990 levels, and it is committed to a $40 \%$ reduction by 2030. In December 2019, the European Commission presented the European Green Pact: a set of measures meant to reduce these emissions by 2030 and also decarbonize the EU economy by 2050, according to the Paris Agreement. In September 2020, the Commission proposed to reduce the GHG emissions by $55 \%$ until 2030 in comparison with the 1990 levels and a neutrality of carbon dioxide emissions by 2050 [3].

In the EU, GHG emissions have been steadily declining since 1990. This act continued in the following years, with emission cutbacks in the EU-28 falling to $23 \%$ below 1990 levels in 2018 and $26 \%$ in 2019 (24\% in the EU - 27 only in 2019). Since 2014, emissions in the EU-28 have consistently remained below the EU's $20 \%$ reduction target for 2020 [4].

*Corresponding author: monicastoica20022002@yahoo.com 
The GHG emission targets as well as the EU Member States (with the exception of the UK) projection are presented in Figure 1 [4].

The Covid-19 pandemic has major implications in terms of achieving 2020 targets. There are strong indications which are not yet quantified, that the economic downturn in 2020 has sharply reduced emissions and energy consumption in that year [4]. For years 2016 - 2030, Romania suggests a national strategy regarding economic growth and climate change based on low carbon emissions. According to this plan, the global share of energy from renewable sources in the final gross energy consumption is $30.7 \%$.

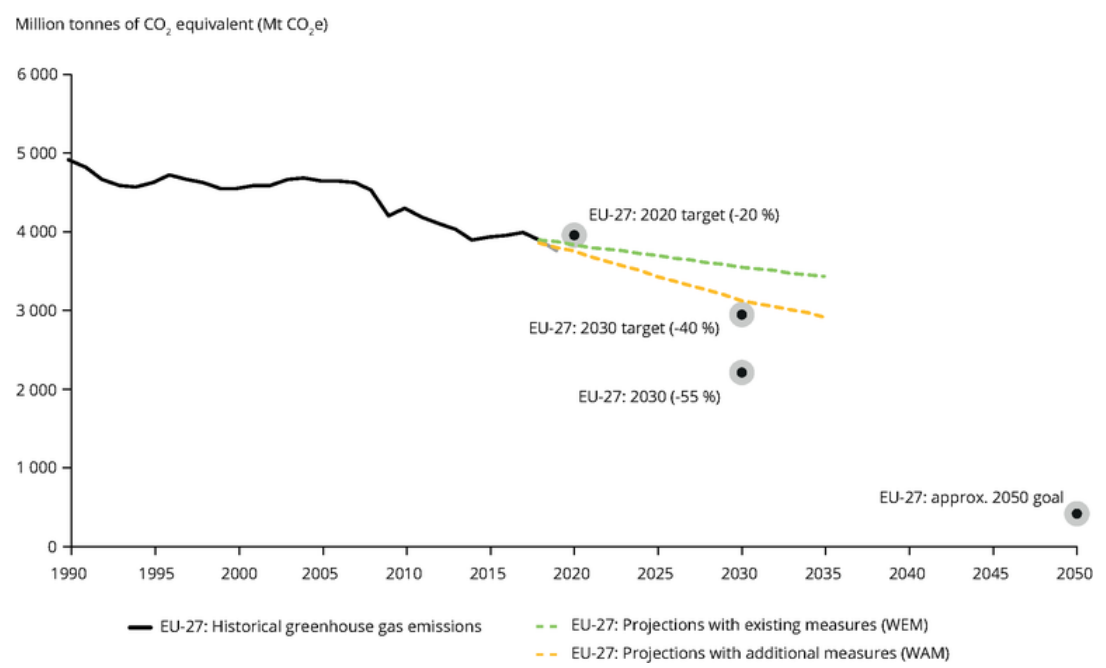

Fig. 1. Greenhouse gas emission targets [4]

For Romania, the intensity of GHG emissions for the period 2013-2018 was carried out by monitoring them [6] and is presented in figure 2 .

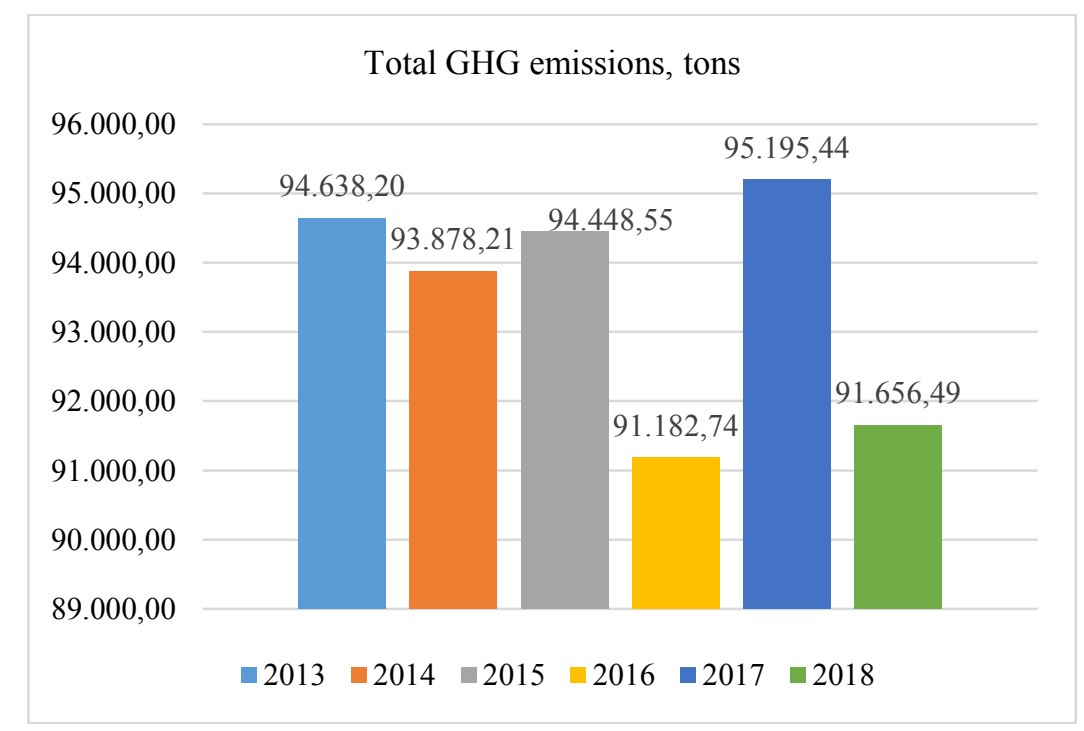

Fig. 2. Total GHG emissions for 2013-2018 
Figure 3 presents the 2018 GHG emissions by sectors of activity; according to [6]. The largest emissions producer is the energy sector.

Greenhouse gases emissions by sector, thousand tones $\mathrm{CO} 2$ echivalent

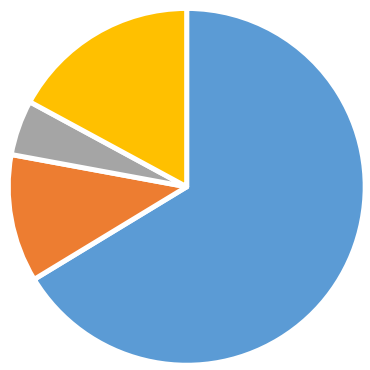

Fig. 3. GHG emission in 2018 , by sector

The Integrated Carbon Observation System (ICOS) quantifies the GHG balance in Europe and other regions. It is a research infrastructure which provides key observations of the greenhouse gas emissions. It evaluates the effectiveness of the carbon sequestration and/ or any greenhouse gas emission reduction activities at global levels of atmospheric composition [7].

Table 1 presents values of $\mathrm{CO}_{2}$ emissions estimated for 2020, as a result of the limitation measures imposed by the Covid - 19 pandemic, for Romania, values in accordance with ICOS $[8,9]$. According to table 1 the lowest quantities in $\mathrm{CO}_{2}$ emissions was in the aviation sector and was due to the reduction in the number of flights.

Table 1. Estimated effect of the confinement measures on $\mathrm{CO}_{2}$ emissions, for Romania $[8,9]$

\begin{tabular}{|c|c|c|c|c|c|c|}
\hline $\begin{array}{c}\text { Total } \\
\mathrm{CO}_{2}, \\
\mathrm{MTCO}_{2} / \\
\text { day }\end{array}$ & $\begin{array}{c}\text { Power, } \\
\mathrm{MTCO}_{2} / \\
\text { day }\end{array}$ & $\begin{array}{c}\text { Industry, } \\
\mathrm{MTCO}_{2} / \\
\text { day }\end{array}$ & $\begin{array}{c}\text { Surface } \\
\text { Transport, } \\
\mathrm{MTCO}_{2} / \\
\text { day }\end{array}$ & $\begin{array}{c}\text { Public, } \\
\mathrm{MTCO}_{2} / \\
\text { day }\end{array}$ & $\begin{array}{c}\text { Residential, } \\
\mathrm{MTCO}_{2} / \\
\text { day }\end{array}$ & $\begin{array}{c}\text { Aviation, } \\
\mathrm{MTCO}_{2} / \\
\text { day }\end{array}$ \\
\hline 0.20290607 & 0.084206015 & 0.04139284 & 0.01095693 & 0.01785573 & 0.04788584 & 0.00040581 \\
\hline
\end{tabular}

During the pandemic, around the world, the energy demands have been incredibly altered by the Government policies. It has been a decrease by $17 \%$ of the daily global $\mathrm{CO}_{2}$ emissions by early April 2020 compared with the 2019 levels. The duration of the restrictions enforces the impact on 2020 annual emissions [10].

\section{Decarbonisation - GHG emissions and absorption}

In order to reach the initial 2050 target, a series of measures and policies have been suggested in reference to the energy and climate change field. The needed measures for the energy sector are the following:

- investing in new low-carbon electricity generation capacities;

- $\quad$ increasing the share of energy from renewable sources;

- producing electricity and heat using cogeneration which is a way to reduce pollutant emissions;

- $\quad$ digitizing the energy system;

- implementing carbon capture solutions, developing emission - free energy production capacity and new carbon storage capacity; 
- $\quad$ promoting the hydrogen use.

The decarbonisation of the transport sector includes:

- using renewable energy for transport: electromobility and biofuels. In Romania, over $14 \%$ of the GHG emissions come from transport.

- $\quad$ using the efficient vehicles (Euro 6) or electric vehicles.

In the decarbonisation process, the circular economy plays an important role. The following measures are being considered:

- increasing the reuse and recycling rate of municipal waste to a minimum of $70 \%$ by 2030 ;

- $\quad$ increasing the recycling rate of packaging waste to $80 \%$ by 2030 ;

- $\quad$ increasing the degree of energy recovery [5].

\section{Biofuels}

One measure regarding the decarbonisation of the transport sector is the use of biofuels. Biofuel is a derived fuel from biomass or algae and plant material or animal waste.

There are four types of biofuels: $1 \mathrm{st}, 2^{\text {nd }}, 3^{\text {rd }}$ and $4^{\text {th }}$ generation biofuels. Fuels derived from crops like starch, corn, animal fats and vegetable oil are first-generation fuels. Firstgeneration biofuels include ethanol, biodiesel and biogas. Biodiesel refers to fuels based on animal fats or vegetable oil. The biogas is a gas typically obtained in the absence of oxygen during the decomposition of organic matter. A biogas can be obtained from biomass, manure, sewage and municipal waste (garbage). The main components of the biogas are methane and carbon dioxide. They are two major greenhouse gases [11]. Non-food crops such as wood, specific biomass crops and organic waste produce the second generation biofuels. The raw material used for the third generation of biofuels are algae. The algae are high-energy and a low-cost [12]. Specially engineered plants or biomass are used to form the fourth generation biofuels. Some efficient "carbon capturing" machines are the biomass crops. Fig 4 shows the processes of capturing $\mathrm{CO}_{2}$ by the fourth generation biofuels. [13].

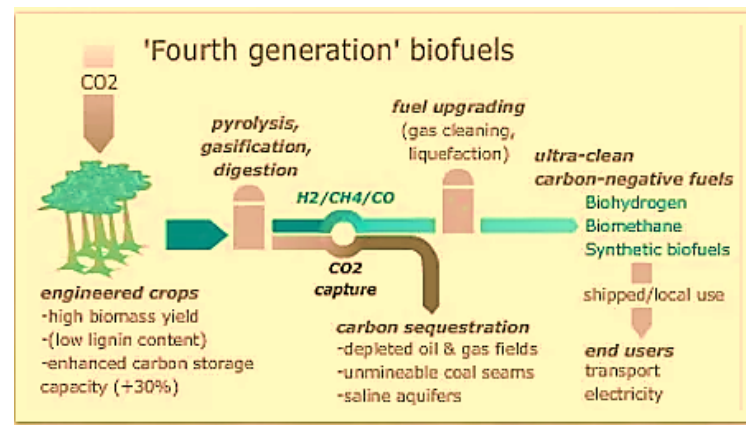

Fig. 4. Fourth generation biofuels [13]

For Romania, according to [6], the consumption of bio-fuel in transports sector, presented in the figure 5 , is increasing. 


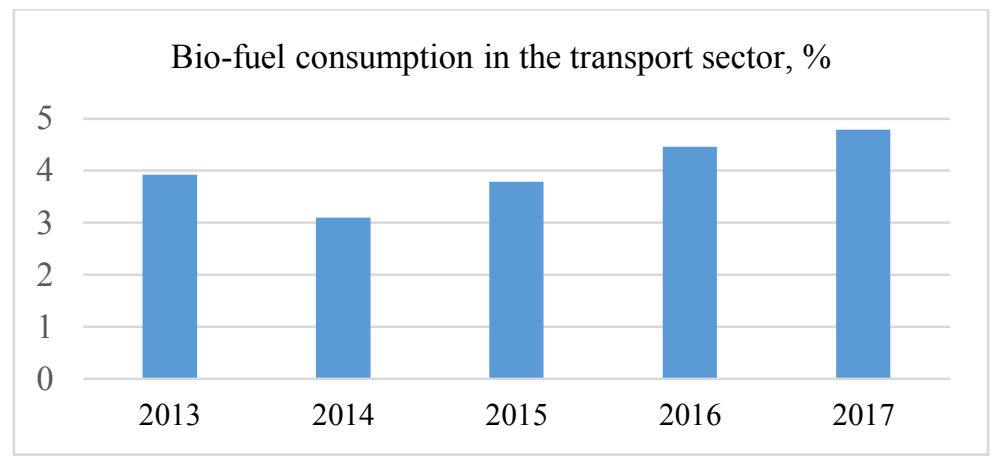

Fig. 5. Bio-fuel consumption in the transport sector

\section{Case Studies}

\subsection{Determination of carbon dioxide emissions for petroleum products}

The polluting effects of fuel combustion are compared by using the carbon dioxide emission coefficient. It represents the ratio of the mass of carbon dioxide which results from combustion to the calorific value of the fuel [14].

$$
\varepsilon_{\mathrm{CO}_{2}}=\frac{m_{\mathrm{CO}_{2}}}{\mathrm{H}}
$$

The following empirical relation can be used to calculate the lower calorific value of petroleum fuels [14]:

$$
H_{i}=46434+3169 \cdot \rho_{15}^{15}-8793 \cdot\left(\rho_{15}^{15}\right)^{2}
$$

$\mathrm{G} / \mathrm{kWh}$ is the measuring unit for carbon dioxide emission.

The carbon dioxide emission coefficient, used for the combustion of liquid petroleum fuels, which are only composed of hydrogen and carbon, can be calculated using the equations in [15] [16]:

- $\mathrm{CO}_{2}$ emissions, calculated according to the lower caloric power:

$$
\varepsilon_{\mathrm{CO}_{2}, I}=\frac{2714+550 \cdot \rho_{15}^{15}}{12.898+0,88 \cdot \rho_{15}^{15}-2.442 \cdot\left(\rho_{15}^{15}\right)^{2}}
$$

- $\mathrm{CO}_{2}$ emissions, calculated according to the higher caloric power:

$$
\varepsilon_{C O_{2}, S}=\frac{2714+550 \cdot \rho_{15}^{15}}{14.529-0.061 \cdot \rho_{15}^{15}-2.442 \cdot\left(\rho_{15}^{15}\right)^{2}}
$$

The petroleum products which are used to determine the carbon dioxide emission coefficient, based on the mathematical model presented, are: Kerosene, LPG, Gasoline Euro 5 and Diesel Euro 5. Their relative densities are presented in table 2. The data in this table are taken from the analysis bulletins and from the safety data sheets of some supplier or distributor companies $[17,18]$.

Table 2. Densities of petroleum products

\begin{tabular}{|c|c|}
\hline Petroleum product & Relative density, $\rho_{15}^{15}$ \\
\hline Kerosene & $0.775-0.840$ \\
\hline Liquefied Petroleum Gas (LPG auto) & 0.523 \\
\hline Gasoline COR 95 Euro 5 & $0.720-0.775$ \\
\hline Diesel Euro 5 & $0.820-0.845$ \\
\hline
\end{tabular}


The results obtained are presented in table 3.

Table 3. Carbon dioxide emission

\begin{tabular}{|c|c|c|}
\hline Petroleum product & $\begin{array}{c}\text { Carbon dioxide emission } \\
\text { calculated according to the } \\
\text { inferior caloric power } \\
{\left[\mathrm{g} \mathrm{CO}_{2} / \mathrm{kWh}\right]}\end{array}$ & $\begin{array}{c}\text { Carbon dioxide emission } \\
\text { calculated according to the } \\
\text { superior caloric power } \\
{\left[\mathrm{g} \mathrm{CO}_{2} / \mathrm{kWh}\right]}\end{array}$ \\
\hline Kerosene & 261.2 & 243.35 \\
\hline $\begin{array}{c}\text { Liquefied Petroleum Gas } \\
\text { (LPG auto) }\end{array}$ & 236.53 & 217.05 \\
\hline Gasoline COR 95 Euro 5 & 254.77 & 236.56 \\
\hline Diesel Euro 5 & 265.29 & 247.66 \\
\hline
\end{tabular}

Table 3 shows that carbon dioxide emissions increase when the relative density of liquid petroleum products increases. Liquefied petroleum gas has lower carbon dioxide emission factors than Gasoline Euro 5 or Diesel Euro 5, which recommends them as fuels to be used for combustion.

\subsection{Determination of carbon dioxide emissions for biofuels}

If the chemical formula of a fuel is known, $C_{m} H_{n} O_{r}$ then the mass fractions can be determined by the relations $[19,20]$ :

$$
\begin{aligned}
g_{C} & =\frac{12 m}{12 m+n+16 r} \\
g_{H} & =\frac{n}{12 m+n+16 r} \\
g_{O} & =\frac{16 r}{12 m+n+16 r}
\end{aligned}
$$

Between the superior and inferior heating value there is the following formula, which is obtained by taking into account the heat necessary for vaporization of water in the fuel gas:

$$
H_{i}=H_{s}-22510 g_{H}
$$

For a biofuel with the chemical formula of $C_{m} H_{n} O_{r}$ the caloric power is calculated as follows:

$$
H_{i}=33900 \cdot g_{C}+120120\left(g_{H}-\frac{g_{O}}{8}\right)
$$

The following relations can be used in order to calculate the emission of carbon dioxide: - $\varepsilon_{\mathrm{CO}_{2}, \mathrm{I}}$ carbon dioxide emission calculated according to the lower caloric power $\left[\mathrm{g} \mathrm{CO}_{2} /\right.$ $\mathrm{kWh}]$ :

$$
\varepsilon_{\mathrm{CO}_{2}, I}=\frac{1000 m}{2.568 m+0.758 n-1.517 r}
$$

- $\varepsilon_{\mathrm{CO}_{2}, \mathrm{~S}}$ carbon dioxide emission calculated according to the superior caloric power $\left[\mathrm{g} \mathrm{CO}_{2}\right.$ $/ \mathrm{kWh}]$

$$
\varepsilon_{C O_{2}, S}=\frac{1000 m}{2.568 m+0.901 n-1.517 r}
$$

The biofuels used in order to determine the carbon dioxide emission coefficient, based on the mathematical model presented, are the following: Bioethanol, Biobuthanol, Biodiesel (soybean) and Biodiesel (rapeseed) [21], for which the chemical formulas are known. The results are presented in table 4. 
Table 4. Results calculation of carbon dioxide emissions for the biofuels combustion

\begin{tabular}{|c|c|c|c|}
\hline Biofuel & Chemical formula & $\begin{array}{c}\text { Carbon dioxide emission } \\
\text { calculated according to the } \\
\text { lower caloric power } \\
{\left[\mathrm{g} \mathrm{CO}_{2} / \mathrm{kWh}\right]}\end{array}$ & $\begin{array}{c}\text { Carbon dioxide emission } \\
\text { calculated according to the } \\
\text { superior caloric power } \\
{\left[\mathrm{g} \mathrm{CO}_{2} / \mathrm{kWh}\right]}\end{array}$ \\
\hline Bioethanol & $\mathrm{C}_{2} \mathrm{H}_{5} \mathrm{OH}$ & 244.89 & 222 \\
\hline Biobuthanol & $\mathrm{C}_{4} \mathrm{H}_{9} \mathrm{OH}$ & 244.87 & 225.16 \\
\hline $\begin{array}{c}\text { Biodiesel } \\
\text { (soybean) }\end{array}$ & $\mathrm{C}_{64.3} \mathrm{H}_{117.7} \mathrm{O}_{6.8}$ & 263.5 & 246.5 \\
\hline $\begin{array}{c}\text { Biodiesel } \\
\text { (rapeseed) }\end{array}$ & $\mathrm{C}_{64.2} \mathrm{H}_{118.8} \mathrm{O}_{6.8}$ & 262.46 & 245.42 \\
\hline
\end{tabular}

Table 4 shows that, the carbon dioxide emission calculated according to the superior calorific power value is less than $222 \mathrm{~g} \mathrm{CO}_{2} / \mathrm{kWh}$ for Bioethanol. The highest value is obtained in the case of combustion of the Biodiesel (soybean), $246.5 \mathrm{~g} \mathrm{CO}_{2} / \mathrm{kWh}$. Regarding the carbon dioxide emission calculated according to the lower caloric power, for Bioethanol is $244.89 \mathrm{~g} \mathrm{CO}_{2} / \mathrm{kWh}$, equal with the Biobuthanol value, $244.87 \mathrm{~g} \mathrm{CO}_{2} / \mathrm{kWh}$ and the highest values is obtained for Biodiesel (soybean), $263.5 \mathrm{~g} \mathrm{CO}_{2} / \mathrm{kWh}$.

The results presented in table 3 and table 4 provides data referring to the $\mathrm{CO}_{2}$ quantity that reaches into the atmosphere, which results from the combustion of petroleum fuels and biofuels. Based on the information obtained, a fuel ranking can be made and decisions can be taken regarding their choice.

Comparing table 3 with table 4 we obtain the following ranking:

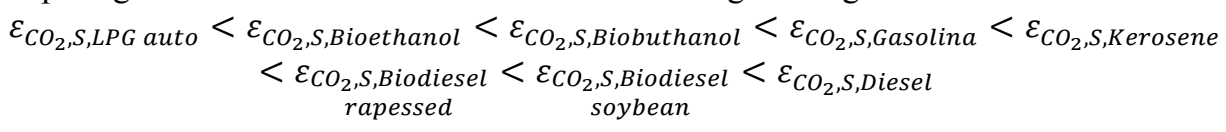

\section{Conclusions}

By estimating the carbon dioxide emission coefficients, it is possible to quantify the effects of pollution in the case of the combustion of petroleum fuels and biofuels.

Knowing the amount of $\mathrm{CO}_{2}$ which results from the combustion of fuels can be a premise in choosing the type of fuel used.

In order to minimize GHG emissions, it is necessary to replace fossil fuels with LPG and biofuels.

The use of biofuels does not mean zero carbon dioxide emissions.

\section{References}

1. T. Cristescu, M. E. Stoica, S. Suditu, Rev.Chim., 70, 585 (2019)

2. L. Avram, T. Cristescu, M. Stoica, E3PE 2017, Carbon Dioxide Emissions Monitoring in Romania in the Context of Greenhouse Gases Reduction, (Beirut, Lebanon, 2017)

3. http://www.europarl.europa.eu, [Accessed 14.03.2021]

4. http://www.eea.europa.eu, [Accessed 14.03.2021]

5. http://www.mmediu.ro/app/webroot/uploads/files/PNIESC_SEA_23.04.2020.pdf, [Accessed 15.03.2021]

6. https://insse.ro/cms/, [Accessed 15.03.2021] 
7. https://ro.qaz.wiki/wiki/Integrated Carbon Observation System, [Accessed 12.03.2021]

8. http://www.icos-cp.eu, [Accessed 12.03.2021]

9. http://www.icos-cp.eu/gcp-covid19, [Accessed 11.03.2021]

10. C. Le Quéré, R. B. Jackson, M. W. Jones, A. J. P. Smith, S. Abernethy, R. M. Andrew, A. J. De-Gol, D. R. Willis, Y. Shan, J. G. Canadell, P. Friedlingstein, F. Creutzig, G. P. Peters, Nat Clim Chang., 10, 647 (2020)

11. http://refuelingthefuture.yolasite.com/, [Accessed 18.03.2021]

12. http://www.pmfias.com/biofuels/, [Accessed 18.03.2021]

13. http://allaboutbiofuels.wixsite.com/biofuels/fourth-generation, [Accessed 15.03.2021]

14. A. R. Cernea, D. Dobrinescu, I. Fagarasanu, A. Covaci, Termotehnica (EDP, Bucuresti, 1969)

15. T. Cristescu, CIEM 2011, Liquefied Natural Gases and Liquefied Petroleum Gases as Complementary Sources of Energy, (Bucureşti, Romania, 2011)

16. T. Cristescu, Transportul şi înmagazinarea gazelor lichefiate (EUPG, Ploieşti, 2012)

17. Www.mcmpetrol.ro, [Accesed 18.03.2021]

18. www.rompetrol.ro, [Accesed 18.03.2021]

19. T. Cristescu, Termotehnica (EUPG, Ploieşti, 2009)

20. T. Cristescu, M., Stoica, Indian Journal of Applied Research, 3, 28 (2013)

21. A. M. Savel'ev, V.A. Skibin, A. M. Starik, ICAS 2014, Evaluation of emission characteristics of gas turbine engines using alternative fuels, (St Petersburg, Russia, 2014) 